\title{
Provider-Perceived Benefits and Constraints of Complete Adherence to Antenatal Care Guideline Among Public Health Facilities, Ethiopia: A Qualitative Study
}

Research

Keywords:

Posted Date: October 15th, 2020

DOl: https://doi.org/10.21203/rs.3.rs-65478/v2

License: (1) This work is licensed under a Creative Commons Attribution 4.0 International License. Read Full License 


\section{Abstract}

The authors have requested that this preprint be withdrawn due to erroneous posting.

\section{Full Text}

The authors have withdrawn this preprint from Research Square. 